\title{
WHAT DETERMINES THE PERMANENT EMIGRATION OF POLES? THE ANALYSIS OF THE SPATIAL DIVERSIFICATION OF CAUSES IN THREE ECONOMIC AGE GROUPS
}

\author{
Karolina LEWANDOWSKA-GWARDA - Elżbieta ANTCZAK
}

(Received: 14 July 2015; revision received: 28 October 2016;

accepted: January 21 2017)

\begin{abstract}
Our paper seeks answers to the following questions: What are the determinants of permanent emigration from Poland and how do they vary for specific economic age groups (pre-working, working, and post-working age)? Do the causes of permanent emigration differ over space in these categories, and if so, how? We applied GIS and ESDA instruments, including geographically weighted regression, which allowed us to identify the variability of regression coefficients in the geographical space. Our research indicated socio-economic factors (among others: poviats budget income, feminisation rate, unemployment rate), which, with varying force and in varying directions, affected the studied variable in specific parts of the country. The analyses were performed on the basis of statistical data on the numbers of de-registrations for residence abroad in Poland's NUTS-4 in three economic age groups (pre-working, working, and post-working age) for the time span from 2005 to 2013.
\end{abstract}

Keywords: permanent emigration, de-registrations, economic age groups, spatial analysis, geographically weighted regression

JEL classification indices: C21, J82, O15

Elżbieta Antczak, corresponding author. Assistant Professor at the Department of Spatial Econometrics, Faculty of Economics and Sociology, University of Lodz.

E-mail: wiszniewska@uni.lodz.pl.

Karolina Lewandowska-Gwarda, Assistant Professor at the Department of Spatial Econometrics, Faculty of Economics and Sociology, University of Lodz. E-mail: lewandowska@uni.lodz.pl. 


\section{INTRODUCTION}

The political changes in Poland, which took place over the last 25 years (e.g. transformation, accession to the Schengen Area, and the European Union), allowed the free movement of people across borders. The first post-accession years saw a spectacular increase in the scale and dynamics of emigration ${ }^{1}$ of Poles, which was mainly caused by Poland's lower economic and social standing in comparison with other European countries and problems on the labour market (McGhee 2012; Miłaszewicz et al. 2015). The World Bank (2006) documented the trend in emigration using the Polish Labour Force Survey data: 20 percent more Poles stayed abroad in 2004 than in 2003. Based on those data, Kaczmarczyk - Okólski (2008) reported that the number of Polish residents who stayed abroad tripled from early 2004 until early 2007, from around 180,000 to around 560,000. The rate of emigration then significantly decreased in 2009 and 2010, firstly due to the global economic crisis and secondly to the return migration of Poles. However, based on contemporary studies conducted by the Central Statistical Office in Poland (CSO), more and more Poles emigrated after the year 2011 (CSO 2014). The number of de-registrations for permanent residence abroad exceeded 32,000 individuals at the end of $2013 .{ }^{2}$ Of these, over $76 \%$ of emigrants were young, i.e. those of working age, ${ }^{3}$ including about $20 \%$ under 18 , while $4 \%$ at the postworking age ( 65 years and above). Moreover, based on the above-mentioned results, a considerable rise in the number of emigrants - of over $51 \%$ compared to the preceding year, i.e. 2012, and of over 55\% compared to 2004 was observed. A significant increase in the post-EU-accession emigration of Poles for temporary and permanent residence 4 took place from 3 to 5 years after Poland's joining the European Union structures (Jończy 2009). Currently, i.e. in the years 2014-2015, another wave of emigration has begun (CSO 2014: 99). As confirmed by research, a growth in emigration still mostly concerns people at the working age and migration for economic reasons (Slany - Ślusarczyk 2013).

A report prepared by Work Service, Poles'Economic Migrations (Work Service 2014), indicates that a decisive factor in the emigration of the young is inequali-

1 According to the definition of the Polish Central Statistical Office, emigration is departure from the country by its usual resident with the intention to stay abroad for a period of at least 12 months (CSO 2014: 456-457).

2 CSO, Local Data Bank, Population, Migrations: http://stat.gov.pl/bdlen/app/ strona.html?p_ name $=$ indeks (accessed June 27, 2015).

3 The working age is 18-64 for males and 18-59 for females: stat.gov.pl/en/ (accessed June 27, 2015).

4 Emigration for permanent residence is the type of migration related to the change of the country of residence for at least 12 months (CSO 2014: 456-457). 
ties in the country's development and thus willingness to improve the standard of living. Countries to which Poles emigrate allow earning higher remuneration, offer easier access to health care services, and better social conditions (Brzozowski 2011). The group of pre-working age individuals emigrates due to the need or willingness to develop education, improve qualifications and language skills, get the first job, or see the world (Jończy et al. 2014; Jończy 2014). In turn, postworking age people's emigration is, first and foremost, connected with missing their children. Another equally important issue is associated with their looking for a better place to live. There is also a group of so-called young pensioners (such as police workers, miners) who emigrate for economic reasons. Nevertheless, irrespective of the migrant's age, a vital and universal factor in making the decision is family reunification. ${ }^{5}$

Due to the effects, pace, flow, and scale of emigration, the phenomenon of migration has long been among the most serious and prominent social, economic, and cultural issues. It has often also posed a political challenge. ${ }^{6}$ Taking into consideration economic, social, and geographical population migration theories (Janicki 2007) and the need to carry out research in this field as outlined in national development strategies and migration policy, it seems justified to ask the question about determinants of emigration. However, an issue that complicates the unambiguous indication of factors determining the phenomenon described in the article is the difficulty in assessing it. The difficulty results from insufficient knowledge of the scope, actual state, and character of migration (not considering the scale of returns that is difficult to determine owing to the so-called migration floating), as well as the greatly multidimensional and complex nature of principles underpinning migration processes. Among the possibilities of identifying and assessing the impact of factors on the volume of emigration is the method drawing on statistics, geography, and spatial econometrics such as geographically weighted regression (GWR), which enables the multifaceted description and analysis of migration processes by taking into account socio-economic relationships and the local character of the course of the phenomenon in particular spatial units as well as spatial relationships.

The main aim of this paper is an attempt at answering the following questions. What are the determinants of permanent emigration from Poland and how do they vary for specific economic age groups (pre-working, working, and post-working)? Do the causes of permanent emigration differ over space in these age categories,

5 http://topmejt.co.uk/emigracja-polakow-na-najwyzszym-poziomie-od-1945-roku/ (accessed June 28, 2015).

6 The scope of this study does not include the consequences of migration processes. For a discussion, e.g., Jończy (2014) and Slany - Ślusarczyk (2013). 
and if so, how? Our research indicated not only socio-economic factors that affected the studied variables (the level of permanent emigration in pre-working, working, and post-working age), but also described the spatial distribution of these factors in the country. The application of GWR enabled the evaluation of the spatial dependency and heterogeneity of emigration according to economic age groups and its determinants.

The analyses were performed on the basis of statistical data concerning the numbers of de-registrations for residence abroad in 379 Poland's NUTS- $4,{ }^{7}$ in three economic age groups: pre-working, working, and post-working age in the years 2005-2013. The GWR model was built for 2013.

\section{DATA ANALYSIS}

\subsection{Preliminary analysis}

According to the CSO definition, a change in the place of residence equals a change in the place of registration. Thus, published statistical data do not fully reflect the actual scale of emigration. They do not take into account an increasingly popular phenomenon of the so-called circulation of population, i.e. territorial movement that does not entail a relatively permanent change in the place of residence. It is a well-known fact that a considerable part of the society stays permanently or temporarily in a place other than their place of registration. These new forms of migration make the statistical assessment of the phenomenon increasingly difficult (Kaczmarczyk - Tyrowicz 2007). The CSO holds a position that data on Poles staying abroad are not representative for the total population and should be analysed and interpreted with caution. ${ }^{8}$ In order to provide the

7 The NUTS classification was formally introduced in Poland in 2005 when the Regulation of the European Parliament and of the Council amending Regulation on the establishment of a common classification of territorial units for statistics (NUTS) entered into force. The NUTS nomenclature divides Poland into hierarchically related territorial units of five levels: three of these have been defined as regional levels, while two as local levels. There are 4211 NUTS units in the present division (as of January 1, 2015). At the regional level: NTUS-1 (6 regions as groups of voivodeships), NUTS-2 (16 voivodeships), NUTS-3 (72 subregions as groups of poviats); Local levels: NUTS-4 (380 poviats, including cities with poviat status) and NUTS-5 (3737 gminas); http://stat.gov.pl/en/regional-statistics/classification-of-territorial-units/classification-of-territorial-units-for-statistics-nuts/the-nuts-classification-in-poland/\#_ftn1 (accessed September 26, 2016).

8 Considering the national and international migration informational needs and difficulties, the concept of the system of international migration statistics in Poland is briefly described by CSO (2011). 
Table 1. Number of emigrants at different working ages per 10.000 people, in selected years

\begin{tabular}{l|c|c|c|c|c|c|c|c|c}
\hline & \multicolumn{4}{|c|}{$\begin{array}{c}\text { Number of emigrants } \\
\text { at pre-working age }\end{array}$} & \multicolumn{3}{c|}{$\begin{array}{c}\text { Number of emigrants } \\
\text { at working age }\end{array}$} & \multicolumn{2}{c}{$\begin{array}{c}\text { Number of emigrants } \\
\text { at post-working age }\end{array}$} \\
\cline { 2 - 11 } & 2005 & 2009 & 2013 & 2005 & 2009 & 2013 & 2005 & 2009 & 2013 \\
\hline Average & 1 & 1 & 2 & 5 & 4 & 7 & 4 & 0 & 0 \\
\hline Maximum & 8 & 6 & 14 & 61 & 35 & 53 & 5 & 8 & 6 \\
\hline Minimum & 0 & 0 & 0 & 0 & 0 & 0 & 0 & 0 & 0 \\
\hline CV, \% & 167 & 98 & 93 & 165 & 119 & 108 & 267 & 273 & 180 \\
\hline Std. dev. & 1 & 1 & 2 & 8 & 5 & 7 & 1 & 1 & 1 \\
\hline Median & 1 & 1 & 1 & 2 & 2 & 4 & 0 & 0 & 0 \\
\hline
\end{tabular}

Note: $\mathrm{CV}$ - coefficient of variation.

Source: Own work.

highest quality of the study, analyses were conducted on the basis of statistical data concerning the numbers of de-registrations for residence abroad. In contrast to the data on temporary emigration, these data are not estimates. Nevertheless, we are fully aware that they do not record all (they suffer from deficiencies we cannot overcome), it is just a sample that does not fully reflect the level of permanent emigration. However, we should emphasise the value of the data because they illustrate trends and the structure of permanent emigration from Poland.

The poviats of Poland differ substantially in their permanent emigration levels and trends. The main processes of emigration per 10,000 people are characterised by values of selected descriptive statistics. The results of the preliminary research are shown in Table 1.

The coefficient of variation was above $10 \%$ in each emigration group every year. Thus, the numbers of emigrants vary considerably at the NUTS-4. We find the spatial heterogeneity of permanent emigration in each of the analysed age groups. There were units where the number of emigrants was high and those where that number was really low. In the period 2005-2013, the highest dispersion was noticed in the group of people at the post-working age (CV: 180\%-273\%, Table 1).

Over the analysed years, the level of foreign permanent emigration at the preworking age rose the most. An increase in the phenomenon of about $227 \%$ was observed in 2013 compared to 2005 . The lowest rise was noted in the emigration of people at the post-working age (approximately $28 \%$ over the studied years). At the level of NUTS-4, units with an increase in emigration as well as poviats that were characterised by a decrease in emigration could be found. The most marked changes took place in the pre-working and working age groups of emigrants. Compared to 2005, in 2013 some poviats were characterised by a very high rise in the level of the variable (a growth of as much as about of $4000 \%$ ). That increase was 
observed in the groups of emigrants at the pre-working and working ages. At the pre-working age, the most substantial and upward changes in that group occurred in the north-eastern and the south-western Poland as well as in some urban areas such as Słupsk, Kiele, Bygoszcz, Poznań, and Jelenia Góra. However, a great decline of emigration in that age category was observed among poviats from the Śląskie, Dolnośląskie, and Zachodnio-Pomorskie voivodeships. The highest rise in the emigration of working age individuals was observed in most parts of the country apart from the poviats located in Mazowia, Opolskie, and north-western Poland.

The "lowest" rise in the number of de-registrations, of above $1000 \%$, was noted at the post-working age in the country's south-western parts (several poviats in the Małopolskie, Dolnośląskie, and Lubuskie voivodeships as well as in the northern units), mostly in the Pomorskie and Warmińsko-Mazurskie voivodeships. Emigrants at the post-working age were less mobile than others. Over the study period, units characterised by a decrease in permanent emigration were much more noticeable on the map than in other age groups. The situation of poviats exhibiting a high or very low level of emigration will be explained by a set of determinants (see Section 4).

The GWR model will indicate the reasons for levels of the phenomenon in each unit separately. Moreover, the decreases and increases in permanent emigration form some spatial clusters, probably due to specific social as well as economic conditions, and thereby it reflects poviats (un)attractiveness. However, it might also arise from spatial interactions. Therefore, in the next section of the study, we will seek an answer to the research question of whether the volumes of emigration in the age groups in NUTS-4 show statistically significant spatial relationships.

\subsection{Spatial relationships}

In order to characterise the spatial structure of foreign permanent emigration in NUTS-4 in 2013, a matrix of spatial relationships was built (close geographic), based mainly on factual justifications. ${ }^{9}$ The global and local Moran's $I$ statistics were applied. The values for global Moran's $I$ statistic fall in the $<-1 ; 1>$ interval (where "-1" means that dissimilar values are next to each other and "1" means that values are clustered together). It examines the global tendency in spatial variations in the sample by concerning hypotheses: $H_{0}$ : observed values of the vari-

9 An analysis of the spatial correlogram was conducted, which indicated that the strongest spatial relationships in emigration processes might be local (migration processes occurring at small distances of up to $100 \mathrm{~km}$ ). 
able are randomly distributed, hence there is no spatial autocorrelation between specific locations, $H_{1}$ : there is spatial autocorrelation. To evaluate the significance of this index, so-called randomisation tests are performed. ${ }^{10}$ Local autocorrelation indicates spatial relationships of a given variable in a specific location with its surroundings, i.e. values of that variable in adjacent locations (according to the assumed matrix W). Measures for local autocorrelation are Local Indicators of Spatial Association (LISA) developed by Anselin (1995). They include the local Moran's $I_{i}$ statistic. A characteristic feature of those measures is that the sum for all locations is proportional to the value of the global autocorrelation measure $\Sigma_{i} L_{i}=\gamma M$. It enables one to recognise not only local autocorrelation, but also heterogeneity patterns as well as to identify areas of non-stationarity, outliers, clusters of high and low values, and homogenous sub-areas (spatial regimes), and decompose the global measure into parts concerning specific locations (Antczak - Lewandowska-Gwarda 2015: 61).

There are some commonly applied measures designed for testing the presence of spatial relationships according to the formula described by weights matrix W (Moran 1950). ${ }^{11}$ The performed analysis indicated the presence of significant and varied interregional relationships (different for specific groups of emigrants) (Table 2).

Table 2. Values of global Moran's I statistics for emigrants at different working ages

\begin{tabular}{|l|l|l|l|}
\hline \multicolumn{1}{|c|}{$\begin{array}{c}\text { Emigrations } \\
\text { at preworking age }\end{array}$} & \multicolumn{1}{c|}{$\begin{array}{c}\text { Emigrations } \\
\text { at working age }\end{array}$} & \multicolumn{1}{c|}{$\begin{array}{c}\text { Emigrations at post- } \\
\text { working age }\end{array}$} \\
\hline Moran's I & 0.35 & 0.56 & 0.58 \\
\hline p-value & $<0.01$ & $<0.01$ & $<0.01$ \\
\hline
\end{tabular}

Note: Spatial autocorrelation analysis was carried out for only one year due to the further econometric GWR estimation.

Source: Own work.

For the selected year and each group of emigrants at the working age, positive and statistically significant Moran's $I$ statistic values were obtained, implying that according to the matrix, the NUTS-4 displayed a tendency to cluster in the space with respect to similar permanent emigration levels. Thus, it can be stated that emigration also took place at a relatively low level, but the strength of the relationships was different in each group. The strongest relationship character-

10 For the algorithm of this test, see, e.g. Le Gallo - Ertur (2003).

11 For the first time, Cliff - Ord (1973) demonstrated the vast potential of this statistic, modifying it for the purpose of spatial analyses. 
ised emigration at the post-working age (Moran's $I_{\text {av }}=0.58$ ). On average, weaker (Moran's $I$ value was about 5\% lower than at the post-working age) but still positive and statistically significant spatial interactions characterised emigration at the working age (Moran's $I_{\text {av. }}=0.56$ ). The lowest values of the positive and statistically significant autocorrelation indices described emigrants at the pre-working age (it could be substantiated by the age of potential emigrants and thus the difficulties of emigration).

The values of global spatial autocorrelation were conditioned by local spatial regimes. Moreover, positive Moran's I statistics proved the presence of clusters
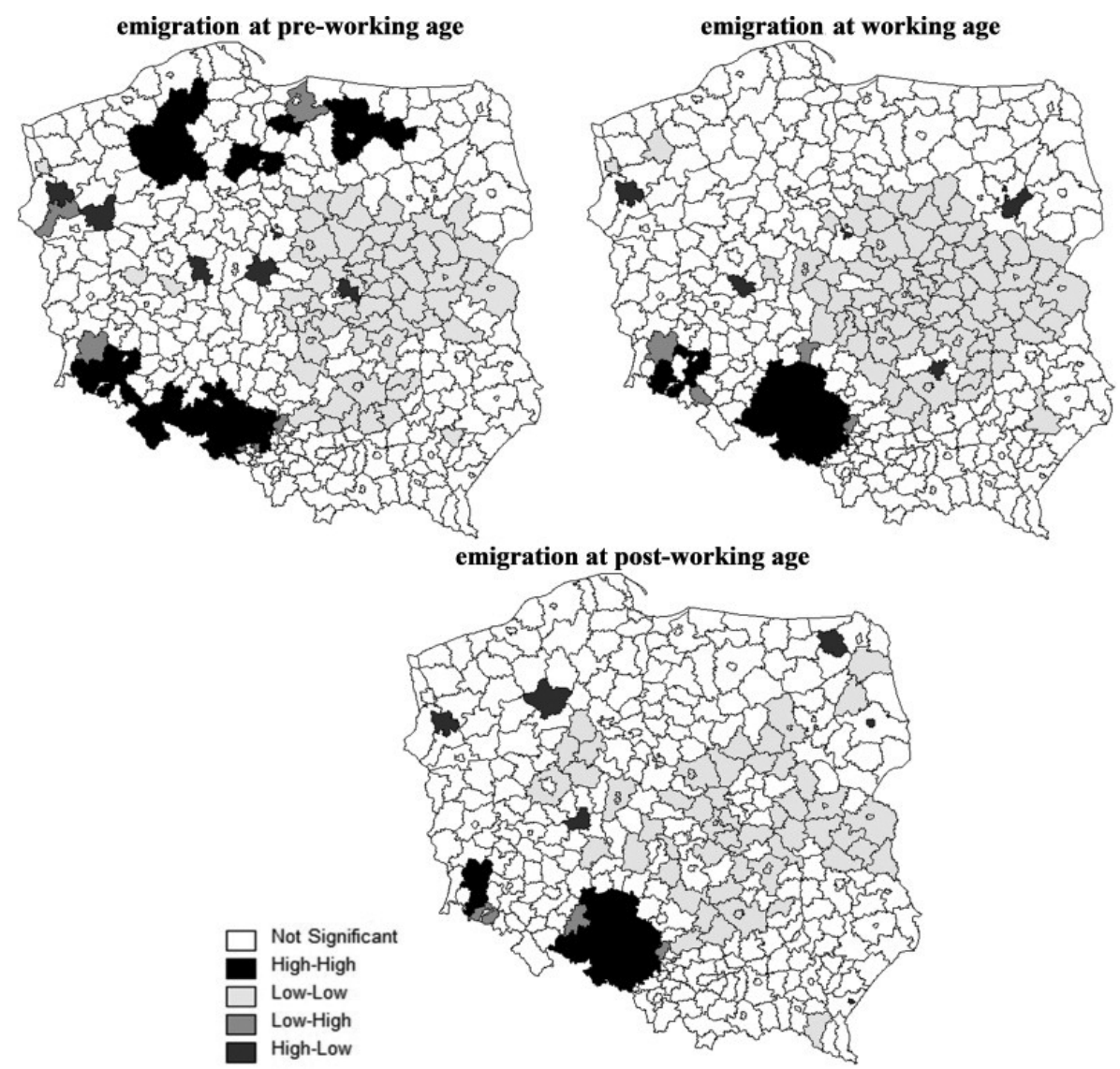

Figure 1. Examples of NUTS-4 according to LISA in each emigration age group in 2013

Note: High-high (hot spots): the level of the variable is high and it is surrounded by units with a high level of the phenomenon too; low-low (cold spots): the level of the variable is low and it is surrounded by units with a low level of the phenomenon too; high-low (outliers): the level of the variable is high and it is surrounded by units with a lower level of the phenomenon; low-high (outliers): the level of the variable is low and it is surrounded by units with a higher level of the phenomenon, according to the $\mathbf{W}$ matrix. 
of NUTS-4 with similar levels of foreign emigration according to the assumed W matrix (Figure 1).

The application of LISA allows detecting clusters in a spatial distribution of emigration processes at the local level. Based on the received results, it can be stated for all age groups that clusters of the lowest scale of de-registrations included the units located in the Mazowieckie, Łódzkie, Świętokrzyskie, and Lubelskie voivodeships as well as in selected poviats in the Zachodniopomorskie and Kujawsko-Pomorskie voivodeships. The clusters of poviats with high levels of permanent emigration (hot spots) characterised southern Poland (Śląskie, Opolskie, and partly the Dolnośląskie voivodeships).

Above all, the statistically significant and factually correct results of the analysis of spatial relationships presented in this section are a formal premise for carrying out further research.

\section{GWR IN MIGRATION ANALYSES}

One of the recent trends in spatial analysis is local modelling by which analysts examine local properties in geographical phenomena. Indeed, spatial processes tend to vary in space due to different geographical contexts so that spatial nonstationarity takes place. In such cases, global models (1) that assume homogeneous (stationary) cross-spatial relationships between dependent and independent variables fail to capture the real phenomena under study.

$$
y_{i}=\beta_{0}+\Sigma \beta_{k} x_{k i}+\varepsilon_{i}
$$

where $y_{i}$ is the dependent variable, $\beta_{k}$ are coefficients, $x_{k i}$ are independent variables, and $\varepsilon_{i}$ is the error term.

Locally linear regression, which was introduced to economics by McMillen (1996), is a relatively recent modelling technique for spatial data analysis. The technique was extended by Brunsdon et al. (1996), Fotheringham et al. (1997, $1998,2002)$ and was also renamed geographically weighted regression. Unlike global regression models, where a single coefficient is estimated for each explanatory variable, GWR allows the estimation of local variations (in space) in those coefficients. This method generates a separate regression equation for each observation, which can be expressed as follows (Brunsdon et al. 1996: 284):

$$
y_{i}=\beta_{0}\left(u_{i}, v_{i}\right)+\sum \beta_{k}\left(u_{i}, v_{i}\right) x_{i k}+\varepsilon_{i},
$$


where $y_{i}$ is the dependent variable, $\beta_{i-}$ are coefficients, $x_{i k}$ are independent variables, $\left(u_{i}, v_{i}\right)$ is the coordinate location of $i$, and $\varepsilon_{i}$ is the error term.

The estimator for the model takes the following form (Charlton - Fotheringham 2009: 5-6):

$$
\beta^{\prime}=\left[\mathbf{X}^{T} \mathbf{W}\left(u_{i}, v_{i}\right) \mathbf{X}\right]^{-1} \mathbf{X}^{T} \mathbf{W}\left(u_{i}, v_{i}\right) \mathbf{Y}
$$

where $\mathbf{W}\left(u_{i}, v_{i}\right)$ is the square matrix of weights relative to the position of $\left(u_{i}, v_{i}\right)$ in the studied area, $\mathbf{X}^{\mathrm{T}} \mathbf{W}\left(u_{i}, v_{i}\right) \mathbf{X}$ is the geographically weighted variance-covariance matrix (the estimation requires its inverse to be obtained), and $\mathbf{Y}$ is the vector of values of the dependent variable.

Each equation is calibrated using different weighting of the observations contained in the data set. The assumption is that observations near one another have a greater influence on one another's parameter estimates than observations further apart according to Tobler's law. The weight assigned to each observation is based on a distance decay function centred on observation $i$ (Mennis 2006: 172).

GWR has an established position in methodological studies and empirical research. Nevertheless, the results of applying this tool in regional analyses of migration have not been popularised in the Polish literature. An example of GWR application in migration analyses was a study on modelling the volumes of internal migration depending on socio-economic processes in Australia and having a major impact on a rise in the country's population. The study was carried out on statistical data concerning 203 local statistical areas in Victoria, with its focus restricted to the regional centre of Bendigo in Victoria (Byrne - Pezić 2004). For Ireland, a study based on the above-mentioned model was conducted by Catney (2006). The article by Jansen - Deller (2007) presented the results of an analysis of the impact of selected factors such as amenities connected with the natural resources of regions and climate conditions on the migration of the elderly in the United States. The study was performed on statistical data concerning 3072 spatial units (districts) in the years 1995-2000. GWR was also used by Jivraj to measure the effect of internal migration on the socio-economic composition of neighbourhoods in 32,482 administrative units of England in 2002-2007 (Jivraj 2011). In 2012, Nakaya applied the presented locally constrained spatial interaction model to test Japanese migration between 727 zones in the 1985-1990 period. The paper by Bajat et al. (2011) considered the possibility of using GWR as an interpolation method for the purpose of mapping the distribution of population flows in the districts of the Republic of Serbia. The effectiveness of GWR was tested by Tamesue - Tsutsumi (2013) on migration flow in 46 units of Japan over the time span of 2005-2006. Moreover, the paper by Jivraj et al. (2013) used the described spatial modelling technique to model family out-migration from neigh- 
bourhoods in England. For Poland, studies on migration flows employing GWR were performed by Lewandowska-Gwarda (2014). The aim of this article was to analyse the spatial distribution of total immigration and emigration in Poland in 2012. Unlike in the previous research, here we examined the spatial diversification of emigration determinants for specific economic age groups. We have not encountered such a broad approach in the Polish literature.

\section{MODELLING PERMANENT EMIGRATION FROM POLAND USING GWR}

Empirical research was performed using three econometric models describing emigration at the pre-working, working, and post-working ages in specific NUTS-4 of Poland in 2013. Due to the fact that variables are non-stationary in space, GWR models were built, which enabled the identification of the local determinants of the variable.

According to the migration theories (push-pull, neoclassical, new economics, dual labour market, network concepts), a variety of socio-economic factors determine the migration processes such as globalisation processes, living standards, labour market conditions, wage level, skills development, and human relationships (Miłaszewicz et al. 2015). The issue of the motives behind Polish international migration has been the subject of several empirical publications. For example, Morawska (2001) provided a detailed analysis of migration mechanisms that took place during the 1990s. Iglicka - Weinar (2005) and Korczyńska (2003) analysed the first stream of emigrants leaving Poland after the country's entry into the European Union. Iglicka et al. (1996) and Sakson (2002) are the other papers on this issue. In fact, many academic studies deal with the directions, scale, and regional differences in emigration along with social, demographic, and economic determinants. ${ }^{12}$

Regrettably, not all variables significant to the presented analysis of permanent emigration were available from Polish public statistics for a NUTS-4 spatial cross-section. These included, for example, information about the number of Polish pupils/students attending foreign schools, number of scholarships granted to them, pension levels, or GDP. Because the GDP variable (describing the level of economic development) was important for this analysis, it was replaced with a local development measure: NUTS-4 budgetary income per capita. Variables of the year 2012 were also introduced into the model due to the fact that according

12 E.g. Kicinger - Weinar (2007), Zborowski - Gałka (2008), Okólski - Salt (2014), Botterill (2014), or Kleinepier et al. (2015). 
to the theory of economics, some variables (unemployment rate and NUTS-4 budgetary income per capita) affect one another with a certain delay.

Finally, the statistical database, contained the following potential determinants: $B$ : live births per 1000 people, $B E$ : number of business entities entered in the register per 1000 people, $B I$ : NUTS-4 budgetary income per capita, $F$ : average floor area per person, $F R$ : feminisation rate (number of women per 100 men), $H A$ : housing allowances per 1000 people in PLN, HR: housing resources per 1000 people, $I$ : capital investments in enterprises for each resident of economically productive age, $J O$ : number of job offers per 10,000 people of economically productive age, $K$ : number of kindergartens per 10,000 people, $N$ : number of nurseries per 10,000 people, $S A$ : share of individuals using community social assistance in the total population, $U R$ : unemployment rate, and $W$ : average wages in PLN.

Based on coefficients of correlation between variables, a set of exogenous variables was specified. Several attempts were made to build the models, taking into account the different sets of explanatory variables and various function forms. Finally, GWR models (after removing statistically non-significant variables) took the following non-linear forms:

\section{Model 1:}

$$
\operatorname{EPRE}_{i 13}=\alpha_{0}\left(u_{i}, v_{i}\right) \cdot \operatorname{EWOR}_{i 13}^{\alpha_{1}\left(u_{i}, v_{i}\right)} \cdot \operatorname{EPOST}_{i 13}^{\alpha_{2}\left(u_{i}, v_{i}\right)} \cdot \operatorname{BI}_{i 12}^{\alpha_{3}\left(u_{i}, v_{i}\right)} \cdot S A_{i 13}^{\alpha_{4}\left(u_{i}, v_{i}\right)} \cdot e^{\varepsilon_{1 i}}
$$

\section{Model 2:}

$$
E W O R_{i 13}=\beta_{0}\left(u_{i}, v_{i}\right) \cdot E P R E_{i 13}^{\beta_{1}\left(u_{i}, v_{i}\right)} \cdot B I_{i 13}^{\beta_{2}\left(u_{i}, v_{i}\right)} \cdot S A_{i 12}^{\beta_{3}\left(u_{i}, v_{i}\right)} \cdot F R_{i 13}^{\beta_{4}\left(u_{i}, v_{i}\right)} \cdot U R_{i 12}^{\beta_{5}\left(u_{i}, v_{i}\right)} e^{\varepsilon_{2 i}}
$$

\section{Model 3:}

$$
\operatorname{EPOST}_{i 13}=\gamma_{0}\left(u_{i}, v_{i}\right) \cdot \operatorname{EPRE}_{i 13}^{\gamma_{1}\left(u_{i}, v_{i}\right)} \cdot \operatorname{EWOR}_{i 13}^{\gamma_{1}\left(u_{i}, v_{i}\right)} \cdot \operatorname{BI}_{i 12}^{\gamma_{3}\left(u_{i}, v_{i}\right)} \cdot S A_{i 13}^{\gamma_{4}\left(u_{i}, v_{i}\right)} \cdot e^{\varepsilon_{3 i}}
$$

where the subscript denotes the year: 12 for 2012 and 13 for 2013, BI the NUTS-4 budgetary income per capita, EPRE the number of de-registrations for residence abroad of pre-working age individuals per 10,000 of the population, EWOR the number of de-registrations for residence abroad of working age individuals per 10,000 of the population, EPOST, the number of de-registrations for residence abroad of post-working age individuals per 10,000 of the population, $F R$ the feminisation rate (number of women per $100 \mathrm{men}$ ), $S A$ the share of individuals using community social assistance in the total population, and $U R$ the unemployment rate.

To compare the results obtained based on the local models, the parameters of the global models were also estimated, given by the following formula: 
Model 1:

$$
\operatorname{EPRE}_{i 13}=\alpha_{0} \cdot \mathrm{EWOR}_{i 13}^{\alpha_{1}} \cdot \mathrm{EPOST}_{i 13}^{\alpha_{2}} \cdot B I_{i 12}^{\alpha_{3}} \cdot S A_{i 13}^{\alpha_{4}} \cdot e^{\varepsilon_{i i}}
$$

Model 2:

$$
E W_{i 13}=\beta_{0} \cdot E P R E_{i 13}^{\beta_{1}} \cdot B I_{i 13}^{\beta_{2}} \cdot S A_{i 12}^{\beta_{3}} \cdot F R_{i 13}^{\beta_{4}} \cdot U R_{i 12}^{\beta_{5}} \cdot e^{\varepsilon_{2 i}}
$$

Model 3:

$$
\operatorname{EPOST}_{i 13}=\gamma_{0} \cdot E P R E_{i 13}^{\gamma_{1}} \cdot E W O R_{i 13}^{\gamma_{2}} \cdot B I_{i 12}^{\gamma_{3}} \cdot S A_{i 13}^{\gamma_{4}} \cdot e^{\varepsilon_{3 i}}
$$

The parameters of global models were estimated using OLS. The estimation of GWR models parameters used an estimator given by the following formula (3). Model 3 was unfortunately characterised by insufficient fit to empirical data, most likely because of the fact that in as many as 130 NUTS-4 post-working age individuals simply did not emigrate in 2013. Acceptable fit was exhibited only by estimates for selected NUTS-4 in the Śląskie, Dolnośląskie, Opolskie, Lubelskie, and Pomorskie voivodeships. Based on the received results, it was observed that an increase in the permanent emigration of post-working age individuals was influenced by a rise in the emigration of pre-working age individuals, especially in poviats located in the Mazowieckie and Świętokrzyskie voivodeships, whereas it was affected by an increase in the emigration of working age individuals in NUTS-4 of the Śląskie and Małopolskie voivodeships. This was connected with the reunification of families. Retirement age people often join their families residing abroad. They usually help their children, e.g. by looking after grandchildren. It was also noted that a decrease in emigration in that age category was affected by the social policy (particularly in poviats of the Lódzkie voivodeships) and economic development of NUTS-4 measured by budget incomes (for instance, in the Lubuskie voivodeships).

Local regression parameter descriptive statistics for Models 1 and 2 are presented in Table 3. In global models, where one parameter is determined for all locations (NUTS-4), it usually equals the median computed for the GWR model. Local models allow the diversification of regression coefficients. Minimum and maximum parameter values indicate how diversified estimations are for specific variables in NUTS-4; sometimes they even have different signs (for the same variables).

Table 4 shows the statistics used for comparing the global and local models describing the emigration of the pre-working and working age population in 2013. All measures indicate the markedly better fit of the local models to empirical 
Table 3. Local regression parameter descriptive statistics: Models 1 and 2

\begin{tabular}{l|c|c|c|c|c|c}
\hline \multirow{2}{*}{ Variable } & \multicolumn{3}{|c|}{ Model 1 } & \multicolumn{3}{c}{ Model 2 } \\
\cline { 2 - 7 } & Minimum & Median & Maximum & Minimum & Median & Maximum \\
\hline Constant & -7.59 & -1.44 & 6.03 & -94.25 & -9.11 & 91.86 \\
\hline $\ln E P R E$ & - & - & - & -0.05 & 0.74 & 1.18 \\
\hline $\ln E$ WOR & 0.01 & 0.71 & 0.96 & - & - & - \\
\hline $\ln E P O P$ & -0.20 & 0.02 & 0.36 & - & - & - \\
\hline $\ln B I$ & -0.001 & 0.0001 & 0.001 & -4.14 & -0.13 & 1.94 \\
\hline $\ln S A$ & -1.34 & 0.22 & 1.60 & -1.86 & -0.35 & 0.74 \\
\hline $\ln U R$ & - & - & - & -2.40 & 0.24 & 2.10 \\
\hline $\ln F R$ & - & - & - & -11.22 & 2.60 & 23.35 \\
\hline
\end{tabular}

Source: Own work.

Table 4. Diagnostic statistics for global and local models

\begin{tabular}{l|r|r|r|r}
\hline \multirow{2}{*}{} & \multicolumn{2}{|c|}{ Model 1 } & \multicolumn{2}{c}{ Model 2 } \\
\cline { 2 - 5 } & \multicolumn{1}{|c|}{ OLS } & \multicolumn{1}{c|}{ GWR } & \multicolumn{1}{c}{ OLS } & \multicolumn{1}{c}{ GWR } \\
\hline Akaike Information Criterion & 719.32 & 679.18 & 800.85 & 782.10 \\
\hline Coefficient of Determination $\left(R^{2}\right)$ & 0.55 & 0.70 & 0.57 & 0.79 \\
\hline Adjusted $R^{2}$ & 0.54 & 0.66 & 0.56 & 0.72 \\
\hline Residual Sum of Squares & 128.95 & 85.28 & 176.79 & 87.06 \\
\hline
\end{tabular}

Source: Own work.

data, both the coefficient of determination, which is higher in the GWR models, and the Akaike information criterion as well as the sum of squares of the residuals whose values were lower.

Figure 2 shows the local values of coefficients of determination for Models 1 and 2. It can be observed that the models were characterised by insufficient fit to data, particularly for NUTS-4 located in the country's eastern part, whereas the fit was best in the country's north and south. The model describing permanent emigration among the pre-working age population was characterised by slightly weaker fit. Nevertheless, both models showed similar fit distribution.

Table 5 presents the spatial diversification of parameter values for the model describing permanent emigration in the pre-working age population and the statistical significance of results. It can be clearly seen that the received estimations were not significant in all locations, while parameter values were diversified in the geographical space. The value whose rise significantly impacted on an increase in emigration of the young (children) across almost the entire country was the emigration of working age individuals (ceteris paribus). The strongest relationship between the variables was observed in the country's northern and 


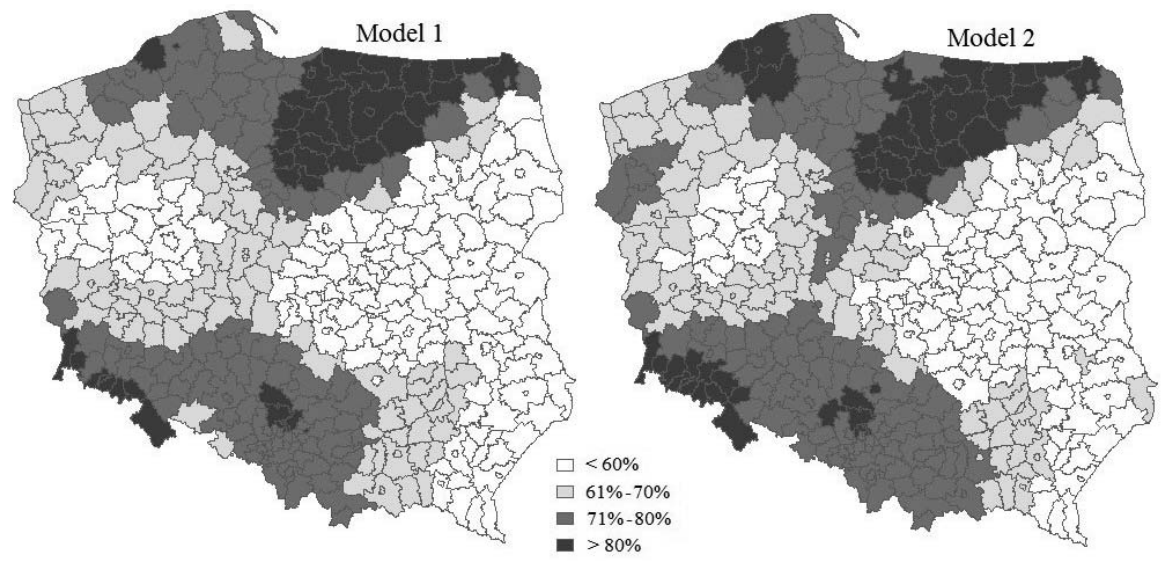

Figure 2. Local adjusted $\mathrm{R}^{2}$ in Models 1 and 2

Table 5. Parameter diversity in Model 1

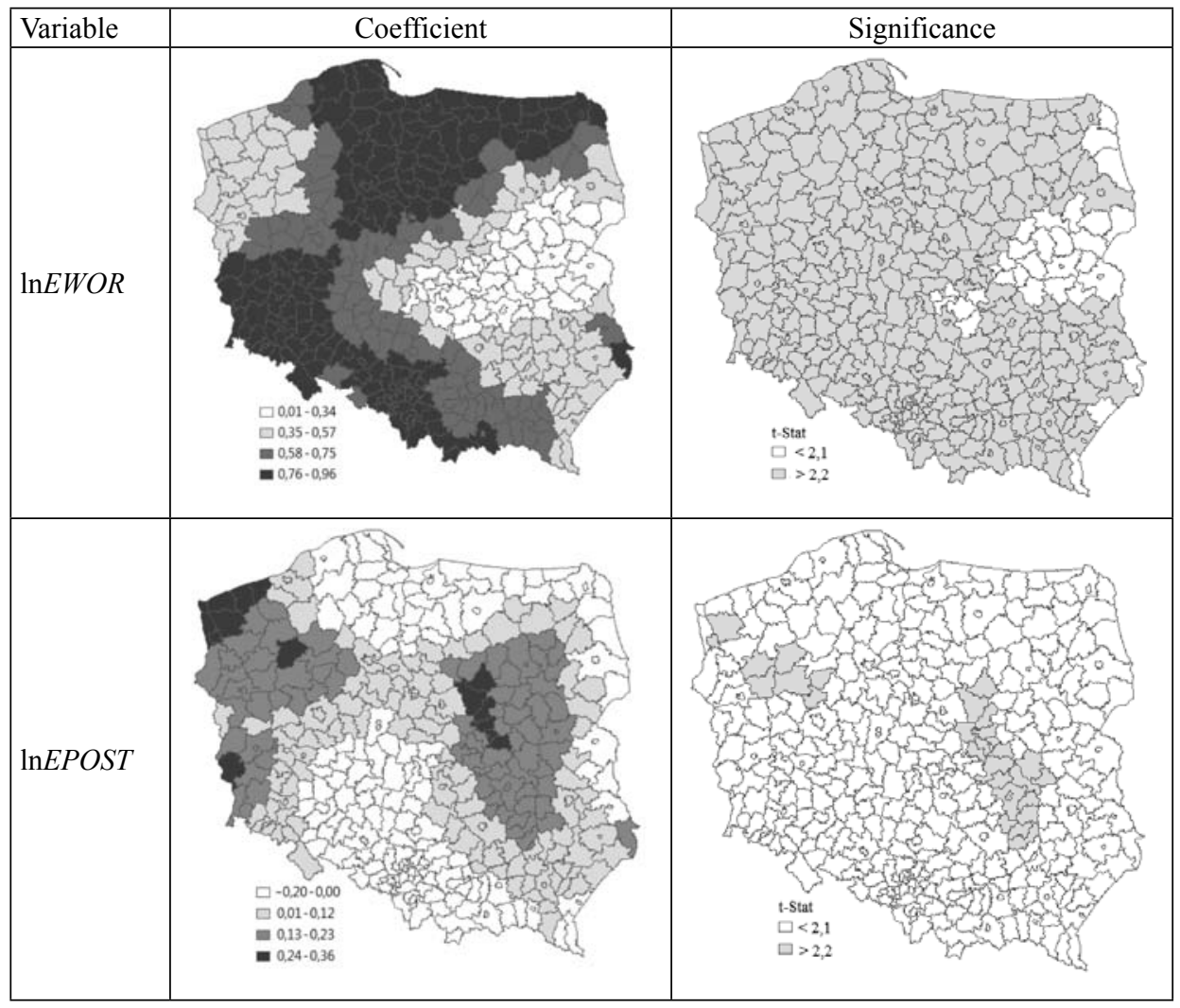


Table 5. continued

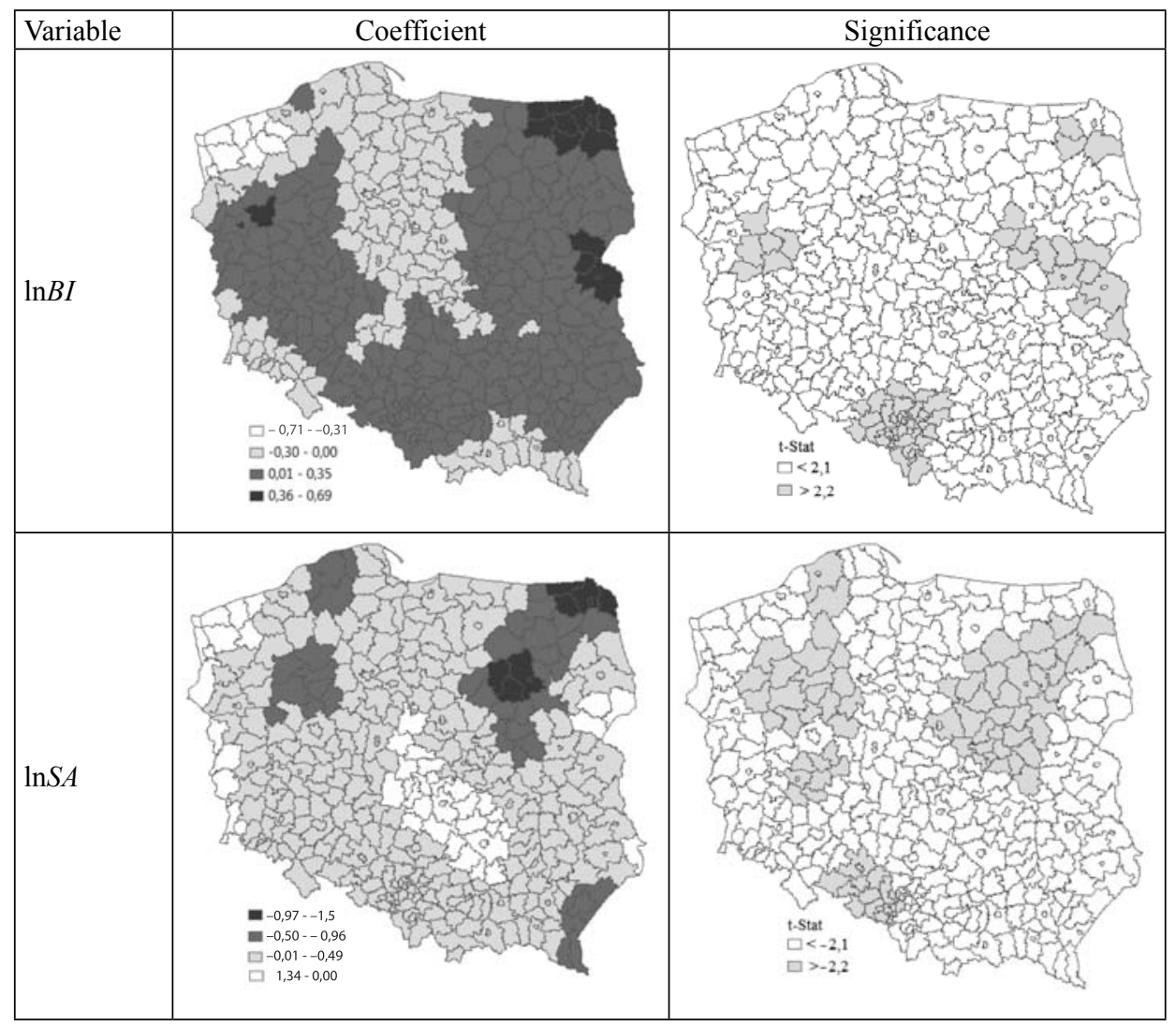

Source: Own work.

south-western parts. At the same time, an increase in the permanent emigration of post-working age individuals influenced a rise in the dependent variable solely in poviats located in the Zachodniopomorskie, Mazowieckie and Świętokrzyskie voivodeships (ceteris paribus). Migrations of different age category individuals affected one another as that was associated with family reunification. In Poland, it is most often one person who decides to emigrate first. When he or she achieves an appropriate financial status, other family members follow.

A rise in the population using social assistance (ceteris paribus) significantly affected a fall in the permanent emigration of pre-working age individuals in NUTS-4 located in the Mazowieckie, Zachodniopomorskie, Wielkopolskie, and Opolskie voivodeships, suggesting that improved social policy could contribute to stopping people's emigration from Poland. In turn, a rise in economic develop- 
ment measured by an increase in poviats budget incomes in the preceding year (2012) affected a growth in the studied variable (ceteris paribus), especially in poviats located in Sląsk. That is quite a surprising conclusion, but perhaps economic development determines, for example, migration of the young associated with sponsored scholarships for education abroad.

Table 6 presents the spatial diversification of parameter values for the model describing permanent emigration in the working age population and the statistical significance of received results. In that case, estimates were not significant for all locations either. An increase in the permanent emigration of pre-working age individuals significantly affected a rise in permanent emigration of the working age population in almost the entire country (ceteris paribus). The impact, however, was the strongest in units located in the country's north-eastern, central and southern part. At the same time, the emigration of post-working age individuals did not show a significant impact on the studied variable. It was also found that a rise in the population using social assistance in the preceding year (ceteris paribus) significantly influenced a fall in the permanent emigration of post-working age individuals in different parts of the country, however, than in model 1 - in NUTS-4 located in the Mazowieckie, Łódzkie, and Wielkopolskie voivodeships. An increase in poviats budget incomes resulted in a decrease in the permanent emigration of working age individuals (ceteris paribus) mainly in units of the Śląskie, Zachodniopomorskie, and Lubelskie voivodeships. Economic growth is tantamount to enhanced well-being (e.g. increased employment, number of job offers, or remunerations), which makes the population meet their financial needs in the country and be unwilling to emigrate. In turn, a rise in the unemployment rate in the preceding year impacted on an increase in the studied variable (ceteris paribus), especially in eastern Poland, where the highest unemployment occurred. It is quite an obvious conclusion because most Poles decide to leave the country due to the very fact that they cannot find employment in their homeland, and thus wish to ensure necessary living conditions for themselves and their families. A rise in the number of women per 100 men resulted in an increase in permanent emigration of working age individuals (ceteris paribus) mainly in the country's central and eastern part (in poviats located in the Lubelskie and Mazowieckie voivodeships. The highest number of women emigrated within the framework of family reunification, but a rise was observed in the number of women independently deciding to emigrate for economic purposes. The specialist literature emphasises that women, more often than men, look for a change of life abroad. They also more commonly mention educational reasons, i.e. acquiring professional experience, language learning, and further education (Szczygielska 2013). 
Table 6. Parameter diversity in Model 2

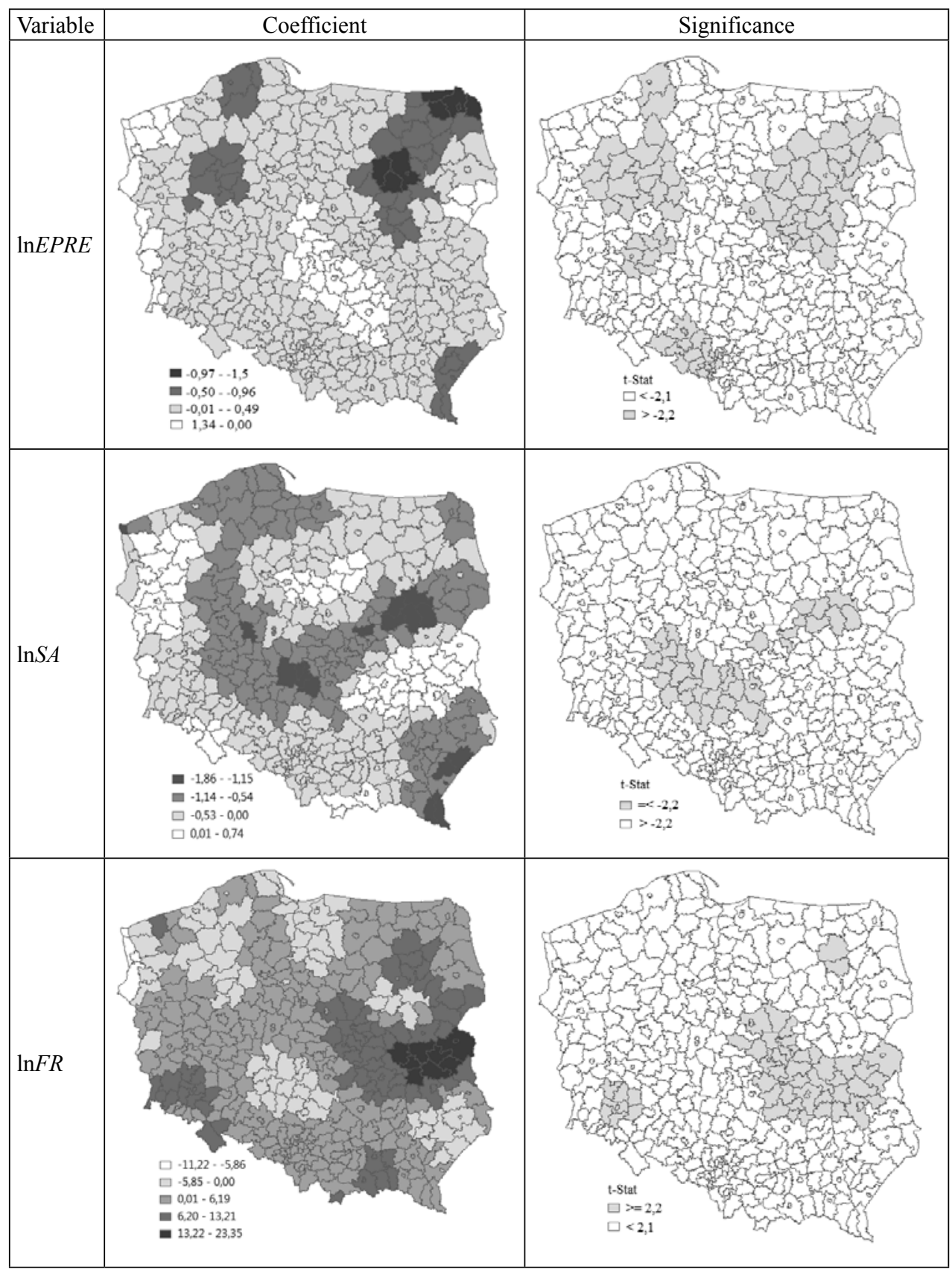


Table 6. continued

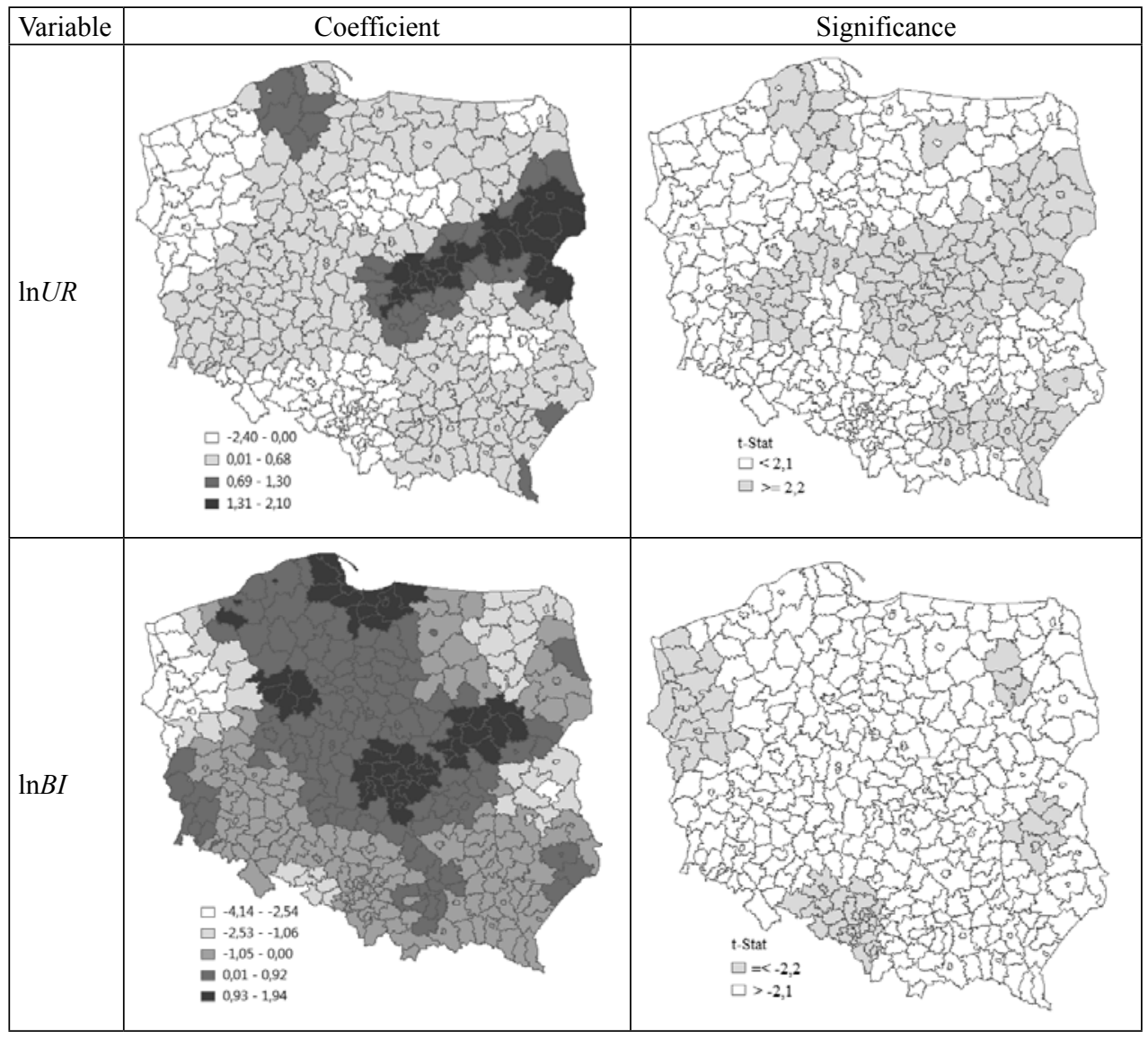

Source: Own work.

It should be emphasised that the set of exogenous variables in the initial forms of the models was considerably wider. Variables such as the number of job offers, the number of economic entities, investment outlays, average wages, housing allowances and housing resources, or the number of live births (per 10,000 of the population), which showed statistical significance in models for total migration (e.g. Lewandowska-Gwarda 2014), did not affect permanent emigration in specific age groups in 2013. 


\section{SUMMARY}

We analysed permanent emigration in Poland using GWR models describing the numbers of de-registrations for residence abroad in three age groups: the preworking, working, and post-working age. An attempt was made to specify and describe a spatial distribution of socio-economic variables that may fundamentally affect the studied phenomenon. The method proved to be an extremely effective instrument of spatial data analysis. Local models were characterised by considerably better fit to empirical data than global ones. They allowed diversifying parameter estimates for specific variables in the geographical space and assessing the significance of received results.

Our empirical findings suggest that economic conditions (which is rather obvious) and human relationships were the main reasons for permanent emigration (correlations between emigration in pre-working, working, and post-working age were very strong in the analysed sample). Currently, family reunification seems to have been the driving force of de-registrations from Poland. Firstly, only one person in the family emigrates. After several years abroad and reaching an appropriate financial status, other family members (partner, children, and even grandparents) follow. Among the economic variables, the economic development (measured by NUTS-4 budgetary income per capita) was the significant factor that makes the population meet their financial needs in the country and be unwilling to emigrate. Moreover, the results of the analyses confirmed that the share of individuals using community social assistance affects the migration processes. An improvement of social policy could perhaps break people's permanent emigration intentions. We also found that the determinants of emigration varied for specific economic age groups in the analysed sample. Moreover, the estimates indicated that for people in the working age group, feminisation rate and unemployment rate were additional factors that turned out to be significant reasons for migration processes. It was also interesting that the emigration of people in post-working age did not affect the emigration of people in working-age (it was the only insignificant relation between emigration processes in specific economic age groups). The application of GWR enabled the identification of the spatial distribution of permanent emigration determinants in the country. For example, in the analysed sample it was observed that an improved social policy could limit the emigration from Poland of the pre-working age population in NUTS-4 living in the Mazowieckie, Zachodniopomorskie, Wielkopolskie, and Opolskie voivodeships, of the working age population in poviats of the Mazowieckie, Łódzkie, and Wielkopolskie voivodeships, and of the post-working age population in NUTS-4 of the Łódzkie voivodeships. 
Due to the generality of statistical information, the received results should be regarded as an experimental estimation and starting point for further analysis. Another stage in the research will be an attempt to build more specific models, for example by considering the lags of the dependent variables, time aggregation, and taking into account the panel character of the data. We think that accounting for the spatial determinants of emigration at economic age groups based on statistical data on NUTS-2 units in the European Union could enrich the analysis. We also plan to construct the spatial weights matrixes in a different way to examine whether there are any non-linearities or asymmetries in directions of population flows.

\section{REFERENCES}

Anselin, L. (1995): Local Indicators of Spatial Association - LISA. Geographical Analysis, 27(2): 93-115.

Antczak, E. - Lewandowska-Gwarda, K. (2015): Migration Processes in European Cities - A Spatio-Temporal Analysis Using Different Spatial Weights Matrices. Estudios de Economía Aplicada, 33(1): 53-80.

Bajat, B. - Krunić, N. - Kilibarda, M. - Samardžić-Petrović, M. (2011): Spatial Modelling of Population Concentration Using Geographically Weighted Regression Method. Journal of the Geographical Institute, Jovan Cvijić, SASA 61(3): 151-167.

Botterill, K. (2014): Family and Mobility in Second Modernity: Polish Migrant Narratives of Individualization and Family Life. Sociology, 48(2): 233-250.

Brunsdon, C. F. - Fotheringham, A. S. - Charlton, M. (1996): Geographically Weighted Regression: A Method for Exploring Spatial Nonstationarity. Geographical Analysis, 28: 281-298.

Brzozowski, J. (2011): Ekonomiczne teorie migracji międzynarodowych (Economic Theories of International Migration). Zeszyty Naukowe Uniwersytetu Ekonomicznego w Krakowie, 855: 55-73.

Byrne, G. - Pezić, A. (2004): Modelling Internal Migration Drivers with Geographically Weighted Regression. Proceedings of the 12th Biennial Conference of the Australian Population Association, 15-17 September 2004, Canberra.

Catney, G. (2006): Internal Migration Flows in Northern Ireland: Exploring Patterns and Motivations in a Divided Society. UPTAP Session 2, RGS-IBG Annual Conference, 2006, http://www. restore.ac.uk/ UPTAP/presentations/event060830/Catney.ppt, (accessed: 28.06.2015).

Charlton, M. - Fotheringham, A. S. (2009): Geographically Weighted Regression. White paper, National Centre for Geocomputation National University of Ireland, Maynooth, http:/gwr.nuim.ie/ downloads /GWR_WhitePaper.pdf, (accessed: 31.01.2015 r.).

Cliff, A. D. - Ord, J. K. (1973): Spatial Autocorrelation. London: Pion.

CSO (2011): The Concept of the International Migration Statistics System in Poland. http://stat. gov.pl/cps/rde/xbcr/gus/p_inter_migration_stat_system_in_poland.pdf (accessed: 21.10.2016).

CSO (2014): Demographic Yearbook of Poland. Statistical Publishing Establishment, Warsaw.

CSO (2014): Population Projection 2014-2050. Demographic Surveys and Labour Market Department, Warsaw 2014, http://stat.gov.pl/files/gfx/portalinformacyjny/pl/defaultaktualnosci/ 5469/1/5/1/ prognoza_ludnosci_na_lata_2014_-_2050.pdf, (accessed: 26.09.2016). 
Fotheringham, A. S. - Charlton, M. - Brunsdon, C. (1997): Measuring Spatial Variations in Relationships with Geographically Weighted Regression. In: Fischer, M. - Getis, A. (eds): Recent Developments in Spatial Analysis. London: Springer Verlag.

Fotheringham, A. S. - Brunsdon C. - Charlton M. (1998): Geographically Weighted Regression: a Natural Evolution of the Expansion Method. Environment and Planning, 30(11): 1905-1927.

Fotheringham, A. S. - Brunsdon, C. - Charlton, M. (2002): Geographically Weighted Regression: The Analysis of Spatially Varying Relationships. U.K.: Wiley.

Iglicka, K. - Jaźwińska, E. - Okólski, M. (1996): Współczesne migracje zagraniczne ludności Polski. Badania etnosondażowe (Contemporary Foreign Migrations of Polish Citizens). Studia Demograficzne, 4: 3-41.

Iglicka, K. - Weinar, A. (2005): Wpływ rozszerzenia Unii Europejskiej na ruchy migracyjne na terenie Polski (Impact of EU Expansion on Migration Flows within Poland). Warsaw: Centrum Stosunków Międzynarodowych, Raporty i Analizy: 1-25.

Janicki, W. (2007): Przeglad teorii migracji ludności (A Review of Population Migration Theory). Wydawnictwo Uniwersytetu Marii Curie-Skłodowskiej (UMCS), Lublin.

Jansen, T. - Deller, S. (2007): Spatial Modeling of the Migration of Older People with a Focus on Amenities. The Review of Regional Studies, 37(3): 303-343.

Jivraj, S. (2011): Modelling Spatial Variations in Neighbourhood Out-Migration with Geographically Weighted Regression. Presentation at BSPS Annual Conference, University of York 7-9th September 2011, http://www.lse.ac.uk/socialPolicy/BSPS/pdfs/2011_Jivraj.pdf, (accessed: 28.06.2015).

Jivraj, S. - Brown, M. - Finney, N. (2013): Modelling Spatial Variation in the Determinants of Neighbourhood Family Migration in England with Geographically Weighted Regression. Applied Spatial Analysis and Policy, 6(4): 285-304.

Jończy, R. (2009): Nowa poakcesyjna emigracja z Polski - perspektywy i zagrożenia oraz możliwości przeciwdziałania (New Post-Accession Emigration from Poland - Prospects and Threats as well as the Possibility of Counteracting) In: Duszczyk, M. - Lesińska M. (eds.): Wspótczesne migracje: dylematy Europy i Polski (Modern Migration: the Dilemmas of Europe and Poland). Ośrodek Badań nad Migracjami, University of Warsaw.

Jończy, R. (2014): Problem nierejestrowanej emigracji definitywnej (emigracji zawieszonej) w badaniu procesów społeczno-gospodarczych na obszarach wiejskich (The Problem of Unrecovered Definitive Emigration (Suspended Emigration) in the Study of Socio-Economic Processes in Rural Areas). Prace Naukowe Uniwersytetu Ekonomicznego we Wrocławiu, Uniwersytet Ekonomiczny we Wrocławiu, No. 360: 11-18.

Jończy, R. - Rokita-Poskart, D. (2014): Educational Migrations as a Factor of the Depopulation of the Intermetropolitan Region. In: Economic and Environmental Studies, University Opolski, (14)1(29): 9-20.

Kaczmarczyk, P. - Okólski, M. (2008): Demographic and Labour-Market Impacts of Migration on Poland. Oxford Review of Economic Policy, 24(3): 599-624.

Kaczmarczyk, P. - Tyrowicz, J. (2007): Współczesne procesy migracyjne w Polsce, a aktywność organizacji pozarzadowych $w$ obszarach powiazanych z rynkiem pracy (Contemporary Migration Processes in Poland and the Activity of NGOs in Labour Market Related Areas). Warsaw: FISE.

Kleinepier, T. - de Valk, H.A.G. - van Gaalen, R. (2015). Life Paths of Migrants: A Sequence Analysis of Polish Migrants' Family Life Trajectories. European Journal of Population, 31(2): $155-179$.

Korczyńska, J. (2003): Sezonowe wyjazdy zarobkowe Polaków do Niemiec (Seasonal Polish Labour Migration to Germany). Warsaw: Wydawnictwo Naukowe Scholar. 
Kicinger, A. - Weinar, A. (eds) (2007): State of the Art of the Migration Research in Poland. CEFMR Working Paper, No. 1/2007, http://www.cefmr.pan.pl/docs/cefmr_wp_2007-01.pdf, (accessed: 22.10.2016).

Le Gallo, J. - Ertur, C. (2003): Exploratory Spatial Data Analysis of the Distribution of Regional Per Capita GDP in Europe, 1980-1995. Papers in Regional Science, 82 (2):175-201.

Lewandowska-Gwarda, K. (2014): Spatial Analysis of Foreign Migration in Poland Using Geographically Weighted Regression. Comparative Economic Research. Central and Eastern Europe, 17(4): 137-154.

Miłaszewicz, D. - Milczarek, A. - Nagaj, R. - Szkudlarek, P. - Zakrzewska, M. (2015): Determinants of Polish International Migration in the Area of the European Union after 2004. Journal of International Studies, 8(3): 62-78.

McMillen, D. (1996): One Hundred Fifty Years of Land Values in Chicago: A Nonparametric Approach. Journal of Urban Economics, 40(1): 100-124

Mennis, J. (2006): Mapping the Results of Geographically Weighted Regression. The Cartographic Journal, 43(2): 171-179.

Moran, P. A. P. (1950): Notes on Continuous Stochastic Phenomena. Biometrika, 37(1): 17-23.

Morawska, E. (2001): Structuring Migration: the Case of Polish Income-Seeking Travelers to the West. Theory and Society, 30(1): 47-80.

Nakaya, T. (2012): Local Spatial Interaction Modelling Based on the Geographically Weighted Regression Approach. GeoJournal, 53(4): 347-358.

Okólski, M. - Salt, J. (2014): Polish Emigration to the UK after 2004. Why did so Many Come? MRU Discussion Paper, http://www.geog.ucl.ac.uk/research/research-centres/migration-research-unit/ discuss ion-papers/ MOJS\%20revise\%20041114_accept.pdf, (accessed: 21.10.2016).

Sakson, B. (2002): Wplyw ,niewidzialnych" migracji zagranicznych lat osiemdziesiatych na struktury demograficzne Polski (Impact of "Invisible” Emigration on the Demographic Profile of Poland in the 1980s). Warsaw: Wydawnictwo SGH.

Slany, K. - Ślusarczyk, M. (2013): Migracje zagraniczne Polaków w świetle NSP 2011. Trendy $i$ charakterystyki socjo-demograficzne (Foreign Migration of Poles in the Light of NSP 2011. (Trends and Characteristics of Socio-Demographic Issues). www.euroemigranci.pl/dokumenty/ pokonferencyjna/Slany_Slusarczyk .pdf, (accessed: 28.06.2015).

Szczygielska, I. (2013): Migracje zarobkowe kobiet i ich wptyw na funkcjonowanie rodzin (Labor Migration of Women and their Impact on Family Functioning). Warsaw: Uniwersytet Warszawski,

Tamesue, K. - Tsutsumi, M. (2013): Geographically Weighted Regression Approach for OriginDestination. http://rri.wvu.edu/wp-content/uploads/2013/07/Fullpaper_3.D.3.pdf, (accessed: 28.06.2015).

World Bank (2006): International Migration, Remittances and the Brain Drain. Washington, D.C.

Work Service. (2014): Migracje zarobkowe Polaków (Poles'Economic Migrations), Work Service S.A. http://www.workservice.pl/content/download/4130/32750/file/Work\%20Service_Raport_ Migracje\%20zarobkowe\%20Polakow_digital_pl.pdf, (accessed: 28.06.2015).

Zborowski, A. - Gałka J. (2008): Migracje stałe i czasowe z Polski po akcesji do Unii Europejskiej (Permanent and Temporary Migration from Poland after Accession to the European Union). In: Ilnicki, D. - Janc, K. (eds): Przekształcenia Regionalnych Struktur Funkcjonalno-Przestrzennych. Rozprawy Naukowe Instytutu Geografii i Rozwoju Regionalnego, Wrocław: 29-37. 


\section{APPENDIX 1}

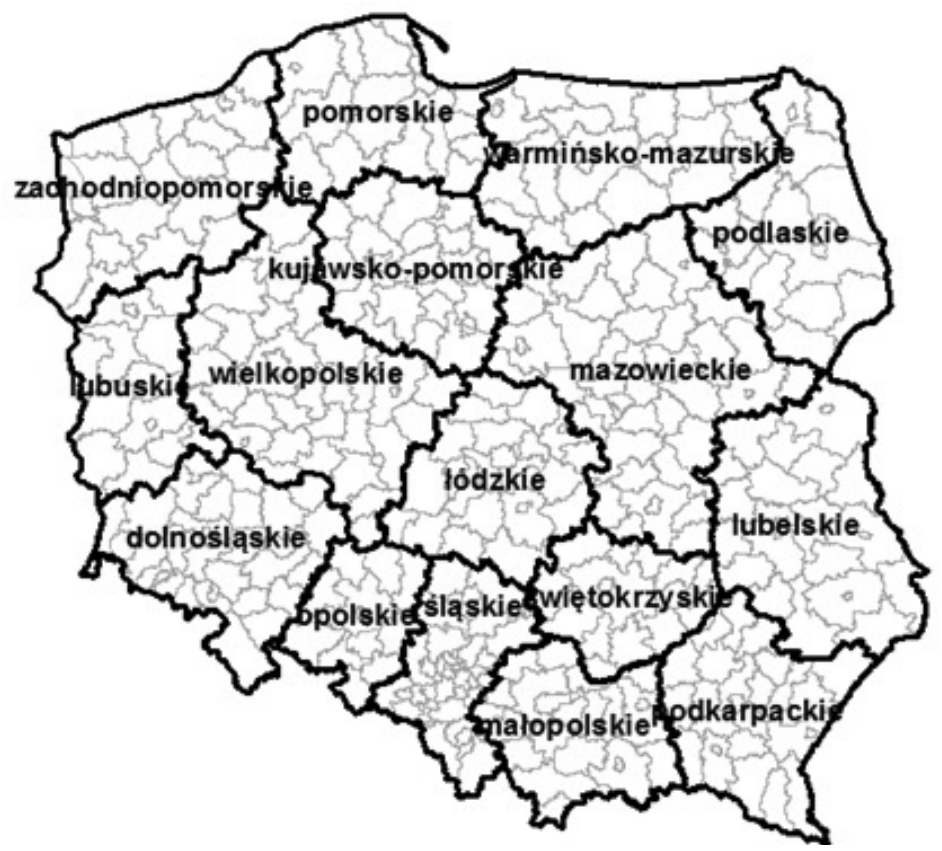

Map of Polish NUTS-2 (voivodeships) 